\title{
Modelling of compressive strength of self-compacting concrete containing fly ash by gene expression programming
}

\author{
İ brahim Özgür Deneme (Main and Corresponding Author) \\ Aksaray University, Civil Engineering Department \\ 68100 Aksaray (Turkey) \\ ideneme@aksaray.edu.tr \\ Manuscript Code: 14104 \\ Date of Acceptance/Reception: 25.06.2020/21.11.2019 \\ DOI: $10.7764 /$ RDLC.19.2.346
}

\begin{abstract}
In the modelling study, two models are presented by gene expression programming (GEP) for estimation of compressive strength $\left(f_{c}\right)$ of selfcompacting concrete (SCC) produced with fly ash (FA). The main difference between two models is the number of heads determined in the development of models. Two established models are proposed to predict the $f_{c}$ values by utilizing the amount of cement, water, FA, coarse and fine aggregate, superplasticiser and age of specimen as input values for SCC mixtures. In the establishment of proposed models, $516 f_{c}$ values are utilized. These values were obtained from 34 different published scientific experimental studies on the SCC produced with FA. The training and testing sets employed in the creation of models consist of $368 f_{c}$ results of SCC mixtures. The models are validated with the remaining $148 f_{c}$ results of SCC mixtures, which are not employed in training and testing sets. The estimated $f_{c}$ results attained from established models were compared with $f_{c}$ results of experimental studies, and previously proposed artificial neural network (ANN) model. These comparisons and the results of statistical evaluation have strongly revealed that the results of established models match well with the experimental results, and they are considered very reliable.
\end{abstract}

Keywords: Self-compacting concrete, Fly ash, Compressive strength, Gene expression programming.

Introduction

Self-compacting concrete (SCC) is a type of concrete evolved in Japan in the 1980s, and later this type of concrete is adopted in the rest of the world. The main property of fresh SCC is capable of spreading under its own weight without vibration. Therefore, it can self-settle without any blocking and segregation (Ozawa, Maekawa, \& Okamura, 1990; Siddique, Aggarwal, \& Aggarwal, 2012b; Sonebi, 2004). Moreover, this type of fresh concrete has three important characteristics which are passing capacity, segregation resistance and filling capacity (Golafshani, Rahai, \& Sebt, 2014; Liu, 2010; Melo \& Carneiro, 2010; Siddique, 2011; Sonebi, 2004; Zhu, Gibbs, \& Bartos, 2001). The mixtures of SCC are different in comparison to traditional concrete. The SCC incorporates such chemical admixtures that provide high flowability. Further more, the water to binder ratio and the ingredient of coarse aggregate of SCC are lower than those of traditional concrete to improve the workability and decrease segregation (Bingöl \& Tohumcu, 2013; Golafshani \& Pazouki, 2018; Khatib, 2008; Mohamed, 2011; Sonebi, 2004). Currently, the SCC has gained wide usage area for structural configurations and different structural applications. Chemical additives used as superplasticizer can increase the cost of SCC (Bouzoubaâ \& Lachemi, 2001). However, the un-use of a vibrator in the placement of SCC reduces cost and provides balance. On the other hand, the employment of mineral admixtures like fly ash (FA) and ground blast furnace slag improves the workability of SCC without raising its cost, where asthey result with a decrease in the amount of superplasticiser used in the mixtures (Bingöl \& Tohumcu, 2013; Siddique, 2011).

FA is a fine-grained residual material obtained from coal combustion in thermal power plant. In general, FA is used by partial replacement with cement in the traditional concrete and in the SCC as a mineral admixture. The employment of FA in concrete mixture improves workability, impermeability and in later years mechanical properties of concrete (Bouzoubaâ \& Lachemi, 2001; Le \& Ludwig, 2016; Sonebi, 2004; Sukumar, Nagamani, \& Srinivasa Raghavan, 2008). The partial substitution of FA with Portland cement significantly advances rheological properties of concrete; therefore, the concrete made with FA requires less superplasticizer to gain a similar workability crosschecked to concrete made with only Portland cement (Khatib, 2008; Le \& Ludwig, 2016; Siddique, 2011; Yahia, Tanimura, Shimabukuro, \& Shimoyama, 1999).

The compressive strength $\left(f_{c}\right)$ of concrete is one of the most considerable parameter in the design of concrete and reinforced concrete structures. The $f_{c}$ value of concrete is determined by experiments, and the $f_{c}$ is closely related with concrete constituents and their ratios. Recently, the soft computing methods with the inclusion of genetic programming, genetic algorithm, neural networks and fuzzy logic have been usually utilized to resolve many complex problems in the engineering areas. Moreover, the prediction algorithms like neural network (Eskandari-Naddaf \& Kazemi, 2017; Nagarajan, Rajagopal, \& Meyappan, 2020; Nakata, Fernández, Carrillo, Haro, \& Pinaud, 2018), fuzzy logic (Topçu \& Sarıdemir, 2008), genetic algorithm (Acar Yildirim \& Akcay, 2019; Lim, Yoon, \& Kim, 2004; Prendes-Gero, Bello-García, 
Coz-Díaz, Suárez-Domínguez, \& Nieto, 2018), gene expression programming (GEP) (Mahdinia, Eskandari-Naddaf, \& Shadnia, 2019) are the most commonly employed methods in the concrete research area to estimate the demanded properties of concrete in design of concrete mixtures to save time and cost.

GEP is a method like genetic programming and genetic algorithms. Main difference between three algorithms exists in the character of individuals. The individuals are nonlinear existences of different shapes and sizes in genetic programming. The individuals are linear sequences of fixed length (chromosomes) in genetic algorithms. The individuals are encoded as linear existences of fixed length that are after wards enounced as nonlinear existences of different shapes and sizes (i.e., simple diagram exhibitions or ETs) in GEP. The coaction of chromosomes and ETs in GEP imports aclear interpretation scheme for interpreting the language of chromosomes into the language of ETs. The varied sets of genetic operators improved to present genetic variety in GEP populations every time procreates prevailing ETs. GEP is highly ambidextrous and far exceeds existing evolutionary techniques (Ferreira, 2001a). Also important is that GEP chromosomes are multigenic, encoding multiple ETs or sub-programs that can be organized into a much more complex program. GEP method has been employed to estimate many properties of concrete in civil engineering. The influence of sample size and shape on the $f_{\mathrm{c}}$ of concrete with FA (Sarıdemir, 2014), the $f_{\mathrm{c}}$ of high performance concrete (Mousavi, Aminian, Gandomi, Alavi, \& Bolandi, 2012), the $f_{c}$ of mortar (Baykasoğlu, Dereli, \& Taniş, 2004), the $f_{c}$ of lightweight concrete (Jafari \& Mahini, 2017), the splitting tensile strength from the $f_{c}$ of concrete (Severcan, 2012), the mechanical properties of concrete produced with recycled aggregate (Gholampour, Gandomi, \& Ozbakkaloglu, 2017), the $f_{\mathrm{c}}$ of mortar (Mahdinia et al., 2019), the elasticity modulus of normal-strength concrete and high-strength concrete (Gandomi, Alavi, Ting, \& Yang, 2013; Sarıdemir \& Severcan, 2016), the split tensile strength and water permeability of high strength concrete (Nazari \& Riahi, 2011), the total specific pore volume of inorganic polymers made from seeded FA and rice husk-bark ash (Nazari, 2019b), the $f_{c}$ of lightweight aluminosilicate geopolymers produced by fine fly ash and rice husk bark ash together with palm oil clinker aggregates (Nazari, 2019a) and the effect of $\mathrm{SiO}_{2}$ and $\mathrm{Al}_{2} \mathrm{O}$ nanoparticles on the $f_{\mathrm{c}}$ of ash-based geopolymers (Nazari \& Riahi, 2013) were predicted by using the GEP method.

The characteristics of SCC produced with FA have been investigated by many researchers. However, with the mathematical formulas, the studies predicting the $f_{c}$ results of SCC produced with FA are very rare in the literature. Therefore, this modelling study has been madeto predict the $f_{c}$ results of SCC produced with FA by using the GEP method. In this modelling study, two models are established in the GEP to estimate the $f_{c}$ of SCC produced with FA. The main difference between two models is the number of heads used in the development of models. These models are proposed to predict the $f_{c}$ values by utilizing the amount of cement, water, FA, coarse and fine aggregate, superplasticiser, and age of specimen of SCC mixtures. In the creation of the proposed models, $516 f_{c}$ results obtained from the experimental studies of the SCC produced with FA at 1, 7, 14, 28, 56, 82, 90, 130, 180 and 365 days in 34 different scientific studies are used. 290 and $78 f_{c}$ results of these experimental studies are employed in the training and testing sets of the established models, respectively. The remaining $148 f_{c}$ results of these experimental studies that are not employed in the training and testing sets were also used to validate the models. The predicted compressive strength $\left(f_{c \text {-pred. }}\right)$ results attained from the GEP models are crosschecked with the experimental compressive strength $\left(f_{c \text {-exp. }}\right)$ results, and previously proposed ANN model (Golafshani \& Pazouki, 2018). These comparisons and statistical analyses have revealed that the results of the GEP models are well matched with the experimental work results and are very reliable.

Experimental database

In order to estimate the $f_{c}$ values of SCC produced with FA by using the GEP models, the experimental data were collected from the literature. The experimental databases consisting of 368 experimental results collected from 25 different literature were used in the training and testing sets of models to be developed in the GEP. The experimental studies, forming the experimental databases used in the training and testing sets, were performed by utilizing results of literature (Abdalhmid, Ashour, \& Sheehan, 2019; Bingöl \& Tohumcu, 2013; Bouzoubaâ \& Lachemi, 2001; Bui, Akkaya, \& Shah, 2002; Da Silva \& De Brito, 2015; El-Chabib \& Syed, 2013; Gesoǧlu \& Özbay, 2007; Güneyisi, Gesoglu, Al-Goody, \& Ipek, 2015; Güneyisi, Gesoglu, \& Özbay, 2010; Khatib, 2008; Le \& Ludwig, 2016; Leung, Kim, Nadeem, Jaganathan, \& Anwar, 2016; Liu, 2010; Mohamed, 2011; Patel, Hossain, Shehata, Bouzoubaâ, \& Lachemi, 2004; Pathak \& Siddique, 2012; Pofale \& Deo, 2010; Şahmaran, Lachemi, Erdem, \& Yücel, 2011; Siad, Mesbah, Mouli, Escadeillas, \& Khelafi, 2014; Siddique, Aggarwal, \& Aggarwal, 2012a; Sonebi, 2004; Sonebi \& Cevik, 2009; Sukumar et al., 2008; Ulucan, Türk, \& Karataş, 2008; Zhao, Sun, Wu, \& Gao, 2015). The cement (C), water (W), FA, coarse aggregate ( $\left.C_{\text {agg }}\right)$, fine aggregate $\left(F_{\text {agg }}\right)$, superplasticizer (SP) used in the SCC mixtures besides the age of specimen (AS) were employed as input parameters in

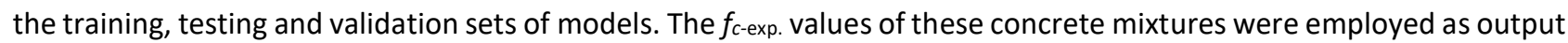
parameter in the training and testing sets of models. Considering the ANN model previously created by Golafshani and Pazouki (Golafshani \& Pazouki, 2018) the training and testing sets were chosen from these databases without any planning where 368 experimental studies of these databases were used in the training set, while 78 experimental 
studies were used in the testing set. The experimental databases consisting of 148 experimental studies collected from 9 different literature were employed in the validation set that was not employed in the training and testing sets to evaluate the performance and acceptability of developed models. The experimental studies, forming the experimental databases used in the validation set, were performed by (Ashtiani, Scott, \& Dhakal, 2013; Jalal, Fathi, \& Farzad, 2013; Khan \& Sharma, 2015; Krishnapal, Rajeev, \& Kumar, 2012; Madihalli, Saunshi, \& Thakai, 2016; Satish, Kumar, \& Rai, 2017; Siddique, 2011; Siddique et al., 2012b; Wang, Zhang, Wang, \& Yu, 2018). The physical, chemical and mechanical properties of the materials obtained from 34 different experimental studies and used as input parameters are different as stated in these studies. Moreover, the amounts of these materials were used differently in the mixtures, and their

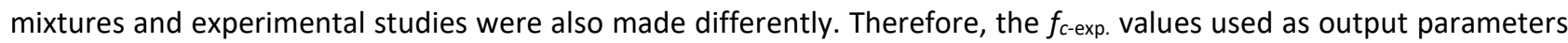
were obtained differently. Figure 1 shows the distributions of variables employed as input parameters in response to

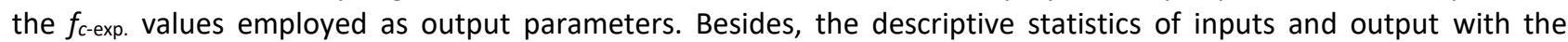
inclusion of maximum (Max), minimum (Min), average (Ave) and standard deviation (SD) of all sets and data count used in the sets are imparted in Table 1 for all databases.

Figure 1. Distribution of (a) $f_{c \text {-exp. }}$. and cement values, (b) $f_{c \text {-exp. }}$. and water values, (c) $f_{c \text {-exp }}$. and fly ash values (d) $f_{c \text {-exp }}$. and coarse aggregate values, (e) $f_{c \text {-exp. }}$. and fine aggregate values, (f) $f_{c \text {-exp }}$. and superplasticizer values and $(\mathrm{g}) f_{c \text {-exp }}$. and age of specimens values. Source: Self-elaboration.

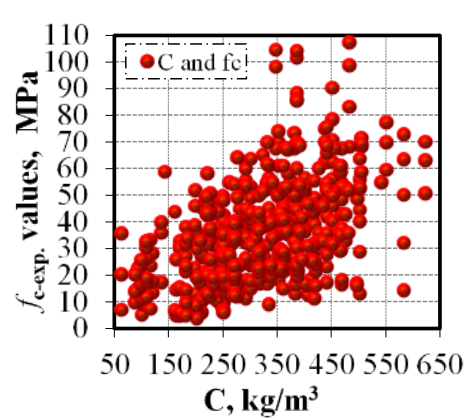

(a)

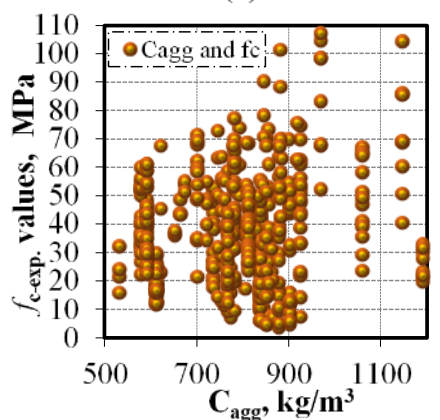

(d)

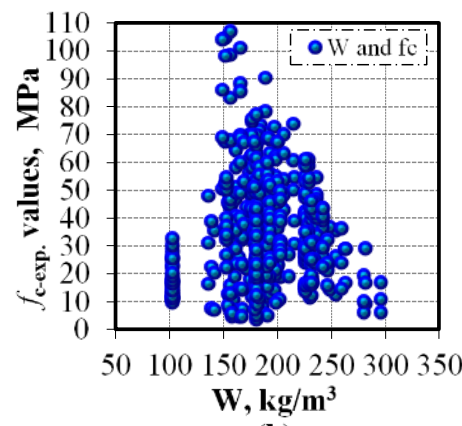

(b)

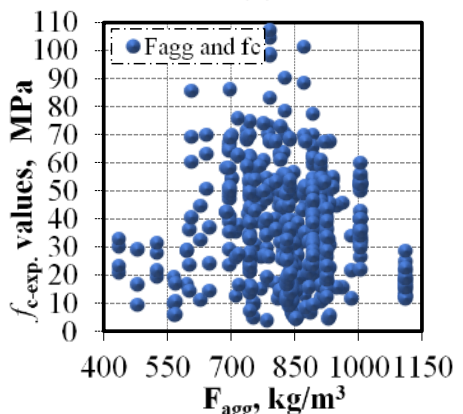

(e)

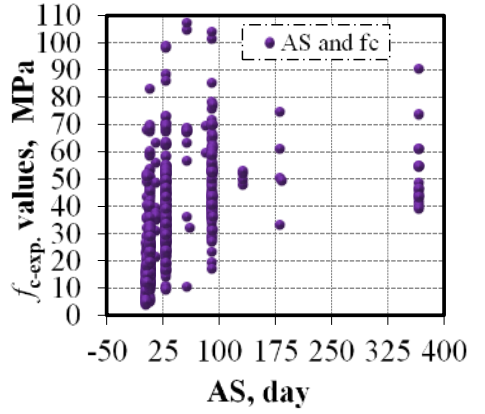

(g)

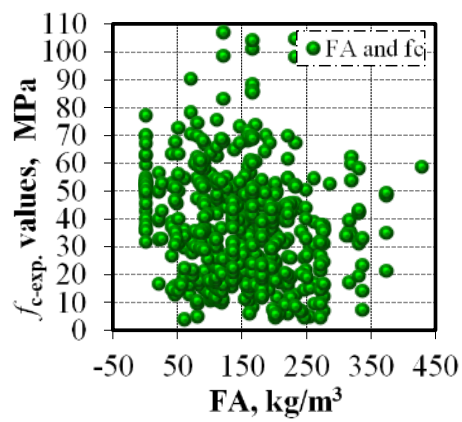

(c)

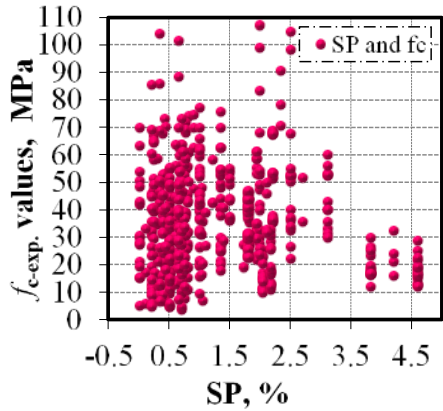

(f)

Table 1. Input and output limits employed in the GEP. Source: Self-elaboration

\begin{tabular}{|c|c|c|c|c|c|c|c|c|c|c|}
\hline Data type & $\begin{array}{l}\text { Data } \\
\text { count }\end{array}$ & $\begin{array}{c}\text { Statistical } \\
\text { parameters }\end{array}$ & $\begin{array}{c}\mathrm{C} \\
\left(\mathrm{kg} / \mathrm{m}^{3}\right)\end{array}$ & $\begin{array}{c}\mathrm{W} \\
\left(\mathrm{kg} / \mathrm{m}^{3}\right)\end{array}$ & $\begin{array}{c}\mathrm{FA} \\
\left(\mathrm{kg} / \mathrm{m}^{3}\right)\end{array}$ & $\begin{array}{c}C_{\text {agg }} \\
\left(\mathrm{kg} / \mathrm{m}^{3}\right)\end{array}$ & $\begin{array}{c}F_{\text {agg }} \\
\left(\mathrm{kg} / \mathrm{m}^{3}\right)\end{array}$ & $\begin{array}{l}\mathrm{SP} \\
(\%)\end{array}$ & $\begin{array}{c}\text { AS } \\
\text { (day) }\end{array}$ & $\begin{array}{l}f_{c \text {-exp. }} \\
(\mathrm{MPa})\end{array}$ \\
\hline \multirow{4}{*}{ All } & \multirow{4}{*}{516} & Min & 61.00 & 102.00 & 0.00 & 530.00 & 434.00 & 0.00 & 1.00 & 4.00 \\
\hline & & Max & 622.00 & 295.20 & 427.50 & 1426.00 & 1820.00 & 4.60 & 365.00 & 107.46 \\
\hline & & Ave & 318.08 & 188.20 & 151.15 & 822.82 & 859.27 & 1.29 & 41.74 & 36.52 \\
\hline & & SD & 113.22 & 35.45 & 77.90 & 193.62 & 186.76 & 1.07 & 67.00 & 19.07 \\
\hline \multirow{2}{*}{ Training } & \multirow{2}{*}{290} & Min & 61.00 & 135.45 & 0.00 & 590.00 & 434.00 & 0.00 & 1.00 & 4.00 \\
\hline & & Max & 622.00 & 295.20 & 427.50 & 1190.00 & 1109.00 & 4.60 & 365.00 & 104.85 \\
\hline
\end{tabular}




\begin{tabular}{|c|c|c|c|c|c|c|c|c|c|c|}
\hline & & Ave & 310.13 & 192.34 & 168.18 & 812.83 & 816.37 & 1.08 & 41.48 & 35.93 \\
\hline & & SD & 106.10 & 29.33 & 79.48 & 123.45 & 121.78 & 1.08 & 61.91 & 19.16 \\
\hline \multirow{4}{*}{ Testing } & \multirow{4}{*}{78} & Min & 61.00 & 135.45 & 0.00 & 590.00 & 478.00 & 0.00 & 1.00 & 5.00 \\
\hline & & Max & 622.00 & 295.20 & 373.00 & 1058.20 & 1109.00 & 4.60 & 365.00 & 107.46 \\
\hline & & Ave & 307.81 & 191.56 & 169.18 & 819.61 & 822.13 & 0.93 & 37.32 & 36.23 \\
\hline & & SD & 111.78 & 32.55 & 76.17 & 107.20 & 109.27 & 0.94 & 53.40 & 19.81 \\
\hline \multirow{4}{*}{ Validation } & \multirow{4}{*}{148} & Min & 86.00 & 102.00 & 0.00 & 530.00 & 605.00 & 0.20 & 3.00 & 10.10 \\
\hline & & Max & 500.00 & 246.00 & 195.00 & 1426.00 & 1820.00 & 4.20 & 365.00 & 104.50 \\
\hline & & Ave & 339.08 & 178.31 & 108.26 & 844.10 & 962.89 & 1.89 & 44.59 & 37.83 \\
\hline & & SD & 124.21 & 44.72 & 56.05 & 306.82 & 266.81 & 0.85 & 81.35 & 18.41 \\
\hline
\end{tabular}

SD is standard deviation, $C$ is Cement, $W$ is Water, FA is Fly Ash, $C_{a g g}$ is Coarse Aggregate, $F_{a g g}$ is Fine Aggregate, SP is Superplasticizer, and AS is Age of Specimen.

Gene expression programming

Gene expression programming (GEP) was evolved by Ferreira (Ferreira, 2001b) using genetic algorithms and genetic programming. GEP is a soft computing method, developed in different shapes and sizes by coding constant-length linear chromosomes. In GEP technique, there are two important components. The first of these is chromosomes. The other is expression trees (ETs). The genetic information code constitutes a free mutual effect between the ETs and the chromosomes (Ferreira, 2001a; Sarıdemir, 2010; Severcan, 2012). In GEP technique, chromosomes constituted in the shape of ETs can be expressed in diverse shapes and sizes by operators and processors. In general, the chromosomes are formed of more than one equal length gene. In addition, the structural and functional organization of chromosomes creates genetic operators such as replication, recombination, mutation and transposition. These genetic operators and processors derive appropriate functions by converting non-linear variables of fixed numbers and lengths into linear arrays of different shapes and sizes (Ferreira, 2001a; Kara, 2011; Sarıdemir, 2010).

All problems, the simplest or the most complex ones, can be expressed by ETs in the GEP. These ETs consist of operators, functions, constants and variables. The relationships between the variables can be expressed with the ET structure (Ferreira, 2001a). Gene numbers, as well as head length, are determined for each problem with respect to the complexity of the problem. The solution of complex problems requires long chromosome structures in the ETs. Because each gene is coded as a smaller and simpler form, then it allows a spatial organization to be a complex structure. Therefore, each genetic code of Sub-unit ET and Sub-ETs is used to solve the problem. Sub-ETs are combined with link functions. These link functions are addition, subtraction, multiplication and division operations.

\section{Development of GEP models}

In the study, in order to estimate the $f_{c}$ values at different ages of SCC produced with FA, four steps were taken into consideration on the models developed inthe GEP technique. First, the fitness function was selected to reach the aim correctly in the prediction of $f_{c}$ values. The most important advantage of the selected fitness functions is that the system can find the most appropriate solution for it self. Second, the terminals and functions were selected for creating the chromosomes. The terminals and functions consist of independent variables. The selection of the appropriate set of functions is not clear, but a good estimate can be made by including all the necessary functions. In this situation, four basic arithmetic operators $\left(+,-,{ }^{*}, / /\right)$ and some basic functions (Mul3, Add3, Exp, Inv) can be selected. Third, the head size and the number of genes to compose the ETs (the chromosomal architecture) were selected. For GEP-based formulations, first, single gene and 2 lengths of heads are used, then the number of genes and heads are increased for the most suitable solution. In the last step the linking function, connecting the Sub-ETs, was selected. In GEP based formulations, multiplication, addition, subtraction and division can be used as linking function. According to these selected steps, two models were developed in the GEP technique to estimate $f_{c}$ values of SCC produced with FA at different ages. In the training and testing of these developed models, C, W, FA, $\mathrm{C}_{\mathrm{agg}}, \mathrm{F}_{\mathrm{agg}}$, SP and AS values were used as input (terminals), and $f_{c \text {-exp. }}$ values were used as output. Here, 290 and 78 of the experimental results were used for training and testing, respectively. The training and testing sets were determined by taking into account the ANN model previously developed by Golafshani and Pazouki (Golafshani \& Pazouki, 2018). In their proposed ANN model, 270 of the experimental results were employed for training, and 68 of the experimental results were employed for testing. However, in the ANN model previously developed, $\mathrm{d} 2=\mathrm{FA}$ input variable did not have a value of 0 , and in order to develop more comprehensive models, new literature data were added to the training and testing sets of GEP models. The definitions function set and the details of other steps used in both GEP models developed with considering the SubETs (gene number or Sub-ETs) and head size on the third step were presented in Table 2. Besides, the effect of genes number on the performance of the models was determined by keeping the chromosome number and head size constant 
in the models. The values in the other definitions are the numbers determined by the GEP technique which shows the effectiveness of the GEP operators mentioned above.

Table 2. Variables employed in the GEP. Source: Self-elaboration

\begin{tabular}{|c|c|c|}
\hline Descriptions & GEP-I & GEP-II \\
\hline Function set & $\begin{array}{l}+,-, *, /, \text { Add3, Mul3, Csc, } \\
\text { Tan, Sin, Ln, X2, Inv }\end{array}$ & $\begin{array}{l}+,-,{ }^{*}, \text { /, Sqrt, Sub3, Add3, Mul3, } \\
\text { Inv, Pow, Tan, Exp, Cos, Ln }\end{array}$ \\
\hline Number of genes & 4 & 5 \\
\hline Constants per gene and head size & & 10 \\
\hline Linking function & Mu & Itiplication \\
\hline Number of chromosomes & & 20 \\
\hline Inversion & & 0.00546 \\
\hline Mutation & & 0.00206 \\
\hline One or two-point recombination & & 0.00277 \\
\hline Transposition and gene recombination & & 0.00277 \\
\hline Random chromosomes & & 0.00260 \\
\hline
\end{tabular}

Sqrt=Square root, Sub3=Subtraction with 3 inputs, Add3=Addition with 3 inputs, Mul3= Multiplication with 3 inputs, Csc=Cosecant, Inv=Inverse, Pow=Power and Exp=Exponential.

The relationship between variables was named as Karva expression by Candida Ferreira (Ferreira, 2001b, 2001a) who developed the GEP algorithm. For predicting at different ages of $f_{c}$ values of SCC produced with FA, the developed ETs, the GEP-I model with 4-Sub-ETs (4-genes or 4-Sub-ETs) and the GEP-II model with 5-Sub-ETs (5-genes or 5-Sub-ETs) were given in Figures 2 and 3, respectively. The purpose of using two different models is to find the model that gives the best results with the effect of the Sub-ETs (genes number). The large number of input variables in both models led to the use of too many ETs and too long chromosome structures. The Karva expressions, which compose of the ETs of the models developed from the GEP-I and the GEP-II, were given in Equations 1 and 2. Moreover, according to ETs, the formula attained from the GEP-I model was presented in Equations 3 and 4, while that of the GEP-II model was presented in Equations 5 and 6 . The symbols seen in ETs; $d 0=C, d 1=W, d 2=F A, d 3=C_{a g g}, d 4=F_{a g g}, d 5=S P$ and $d 6=A S$ are denote the input variables. The constants indicated by ci $(i=1,2, \ldots, 9)$ in the Sub-ETs in the GEP models were given in Table 3. If the necessary constants and input variables are substituted in Equations 3 and 5, the simplified formulas obtained from the GEP-I and the GEP-II models are as presented in Equations 4 and 6. After obtaining these formulas, the validations of them were made with 148 independent data obtained from the literature, which were not employed in the training and testing sets of the models.

+.Add3.*.Add3.*./.*.Csc./.Add3.d1.d6.c9.d4.c0.d5.d5.c1.d1.c7.d0.d2.d0

${ }^{*}$-.d0.Csc. ${ }^{*}$.Mul3.*.+.-.Tan.c8.c7.d5.c8.c6.d3.d4

${ }^{*}$ Add3.*.d0.c9.Ln.X2.X2./.d6.c9.c2

*Inv.-.d3.*.Mul3.Tan.+.Add3.d1.Sin.c4.d0.d1.d6.c8.c4

-.-.*.Sqrt.*.Add3.-.Mul3.Sub3.Sub3.d0.c4.d0.d3.c4.d2.d3.d0.d4.d1.d5.d2.d5.c8

*Inv.Mul3.-.X2.c4.c6.Inv.c6.Sub3.Pow.d2.d6.d3.c1

*Inv.Add3.+.c5.d1.Tan.Exp.+.d5.+.d0.d1.c3

*+.c3.Mul3.Cos.Inv.d3.*.Sub3.+.Sub3.d0.d4.d4.d0.c8.d3.c0.c0

*Ln.*.d6.-.c2.Tan.Cos.+.Mul3.Mul3.d5.c9.c8.d3.c0.d1

$f_{c-\text { pred.- }-1}=\left((((\mathrm{d} 1 / \mathrm{c} 7)+(\mathrm{d} 0+\mathrm{d} 2+\mathrm{d} 0)+\mathrm{d} 1)+(\mathrm{d} 6 * \mathrm{c} 9)+(\mathrm{d} 4 / \mathrm{c} 0))+\left((\mathrm{d} 5 * \mathrm{~d} 5)^{*}(\mathrm{Csc}(\mathrm{c} 1))\right)\right)$

$*(\mathrm{~d} 0-(\operatorname{Csc}((((\mathrm{d} 5+\mathrm{c} 8) *(\mathrm{c} 6-\mathrm{d} 3) * \operatorname{Tan}(\mathrm{d} 4)) *(\mathrm{c} 8 * \mathrm{c} 7)))))$

$*\left(\left(\operatorname{Ln}\left(d 6^{2}\right) *\left((c 9 / c 2)^{2}\right)\right)+d 0+c 9\right)$

$*(1 /((d 3-(((c 4+d 0) *(d 1+d 6+c 8) * d 1) * \operatorname{Tan}(\operatorname{Sin}(c 4))))))$

$f_{c \text {-pred.- }-1}=\left(2 \mathrm{C}+\mathrm{FA}+0.44 \mathrm{~W}+4.933 \mathrm{AS}+0.25 \mathrm{Fagg}_{\mathrm{ag}}-18.438 \mathrm{SP}^{2}\right)$

*(C-Csc $\left(\left((S P-5.135) *\left(6.829-C_{a g g}\right) *\left(\operatorname{Tan}\left(\mathrm{F}_{\mathrm{agg}}\right)\right) *(37.532)\right)\right)$

$*\left(\left(\operatorname{Ln}\left(\mathrm{AS}^{2}\right) * 103.276\right)+\mathrm{C}-84.44\right)$

$*\left(1 /\left(\left(C_{\text {agg }}-(((24.575+C) *(W+A S+5.304) * W) * 0.007)\right)\right)\right)$ 
Figure 2. Expression tree for the empirical model obtained from the GEP-I. Source: Self-elaboration.

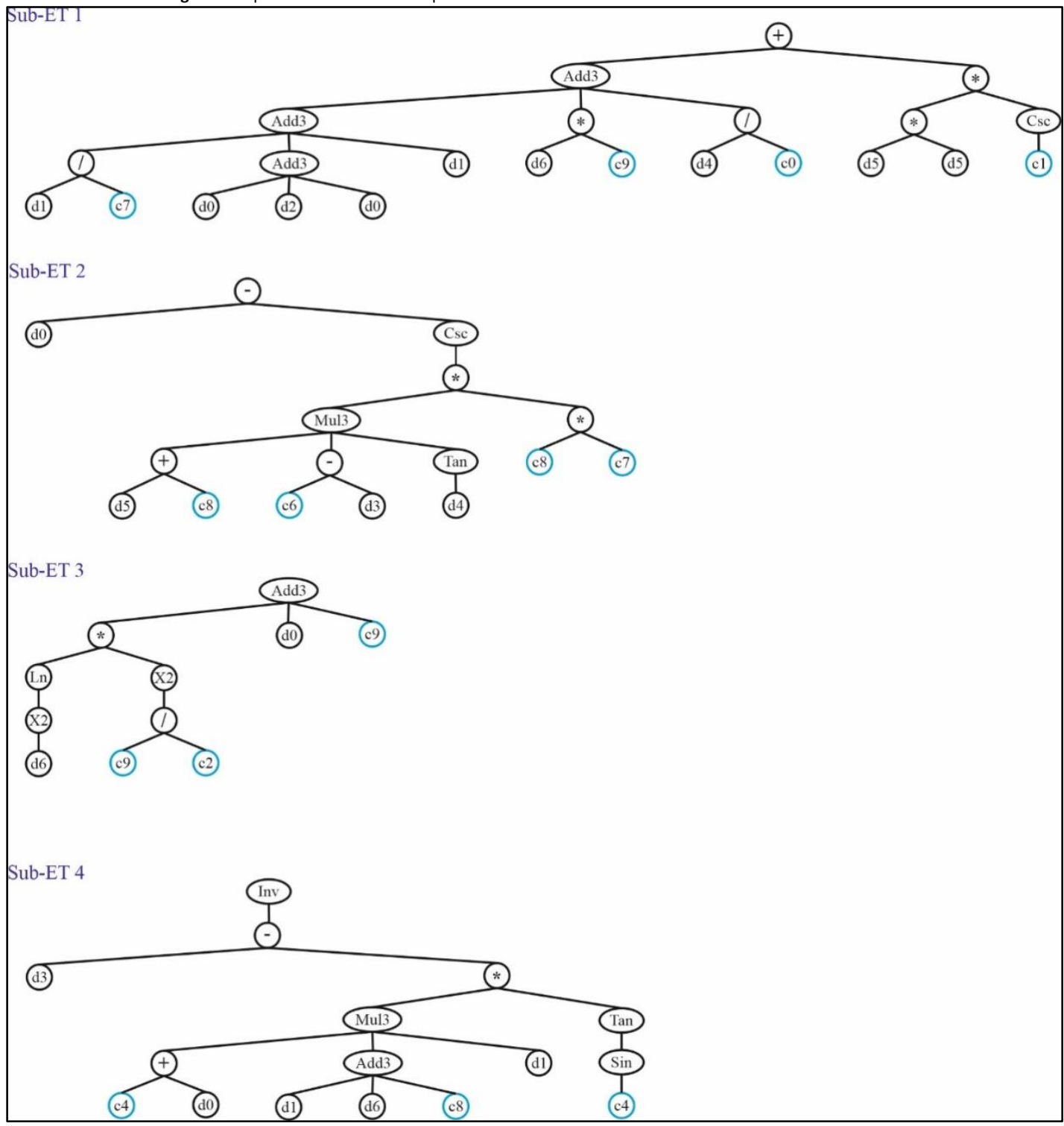

$f_{c \text {-pred- }-11}=((\operatorname{Sqrt}((\mathrm{d} 2 * \mathrm{~d} 3 * \mathrm{~d} 0))-((\mathrm{d} 4-\mathrm{d} 1-\mathrm{d} 5) *(\mathrm{~d} 2-\mathrm{d} 5-\mathrm{c} 8)))-((\mathrm{d} 0+\mathrm{c} 4+\mathrm{d} 0) *(\mathrm{~d} 3-\mathrm{c} 4)))$

$*\left(1 /\left(\left(\left(c 6-\left(1 /\left(\left(\left(d 3^{c 1}\right)-d[2]-d 6\right)\right)\right)\right) *\left(c 6^{2}\right) * c 4\right)\right)\right)$

$*(1 /(((\tan (((d 1+c 3)+d 0))+\operatorname{Exp}(d 5))+c 5+d 1)))$

$*(c 3+(\cos (((d 0+c 8) *(d 3-c 0-c 0))) *(1 /((d 0-d 4-d 4))) * d 3))$

$* \operatorname{Ln}((\mathrm{d} 6 *(\mathrm{c} 2-\operatorname{Tan}(\operatorname{Cos}(((\mathrm{d} 5 * \mathrm{c} 9 * \mathrm{c} 8)+(\mathrm{d} 3 * \mathrm{c} 0 * \mathrm{~d} 1)))))))$

$f_{c \text {-pred.-II }}=\left(\left(\right.\right.$ Sqrt $\left(F A * C_{\text {agg }} * C\right)-(($ Fagg-W-SP $\left.\left.) *(F A-S P+27.585))\right)-\left((2 \mathrm{C}-124.752) *\left(C_{\text {agg }}+124.752\right)\right)\right)$

$*\left(1 /\left(\left(\left(6.280-\left(1 /\left(\left(\left(C_{\text {agg }}{ }^{0.839}\right)-\mathrm{FA}-\mathrm{AS}\right)\right)\right)\right) *(393.280)\right)\right)\right.$

$*(1 /(((\operatorname{Tan}(((\mathrm{W}-1.208)+\mathrm{C}))+\operatorname{Exp}(\mathrm{SP}))-39.00+\mathrm{W})))$

$*\left(-5.48+\left(\operatorname{Cos}\left(\left((\mathrm{C}+4.99) *\left(\mathrm{C}_{\mathrm{agg}}-17.362\right)\right)\right) *\left(1 /\left(\left(\mathrm{C}-2 \mathrm{~F}_{\mathrm{agg}}\right)\right)\right) * \mathrm{C}_{\mathrm{agg}}\right)\right)$

$*\left(\operatorname{Ln}\left(\mathrm{AS}^{*}\left(4.979-\operatorname{Tan}\left(\operatorname{Cos}\left(0.943 \mathrm{SP}-8.681 \mathrm{C}_{\mathrm{agg}} * \mathrm{~W}\right)\right)\right)\right)\right)$ 
Figure 3. Expression tree for the empirical model obtained from the GEP-II. Source: Self-elaboration.

Sub-ET 1

$\odot$

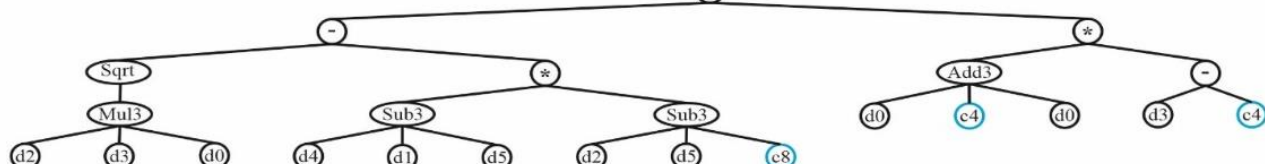

Sub-ET 2
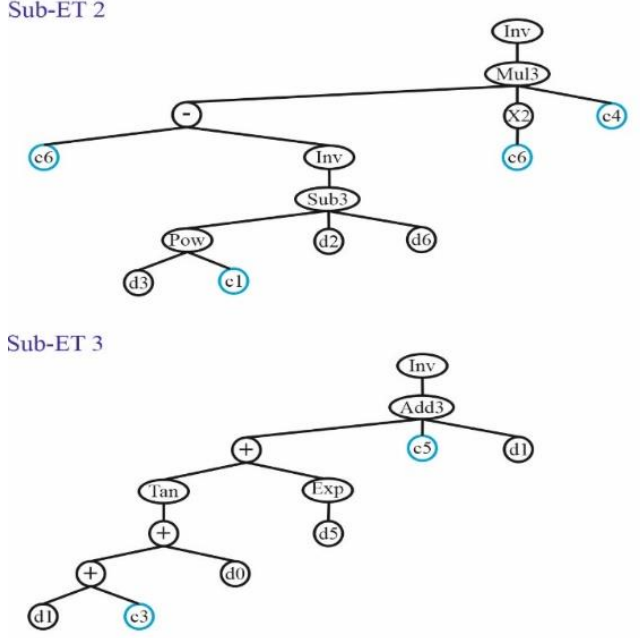

Sub-ET 4

$\oplus$
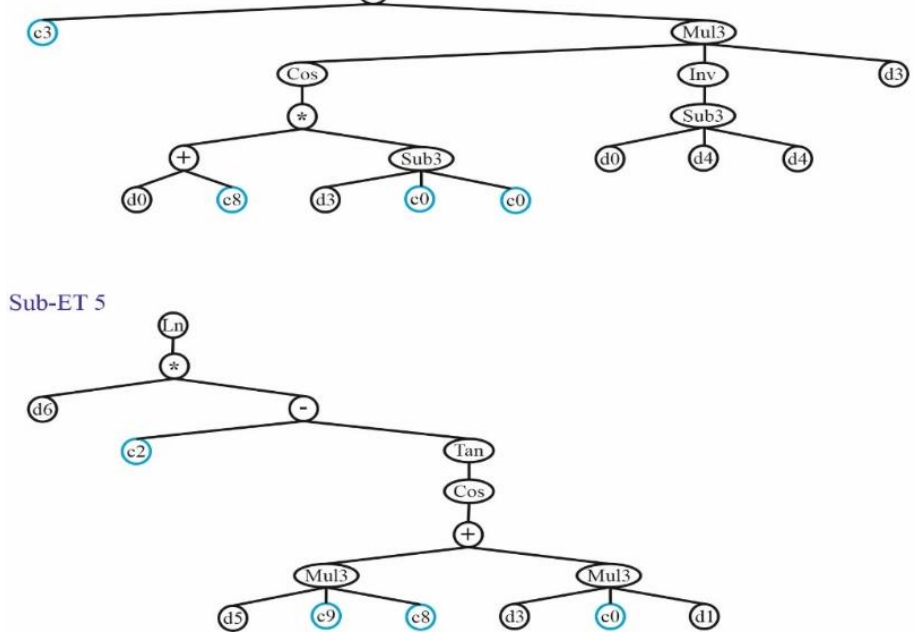

Table 3. Fixed numbers employed in the GEP. Source: Self-elaboration.

\begin{tabular}{|c|c|c|c|}
\hline Sub-ETs & Constants & GEP-I & GEP-II \\
\hline \multirow{6}{*}{ Sub-ET 1} & $\mathrm{cO}$ & 4.000 & \\
\hline & c1 & -3.109 & \\
\hline & $c 4$ & & -124.752 \\
\hline & c7 & -1.790 & \\
\hline & c8 & & -27.585 \\
\hline & c9 & 4.933 & \\
\hline \multirow{5}{*}{ Sub-ET 2} & c1 & & 0.839 \\
\hline & $c 4$ & & 9.972 \\
\hline & c6 & 6.829 & 6.280 \\
\hline & c7 & -7.309 & \\
\hline & c8 & -5.135 & \\
\hline \multirow{4}{*}{ Sub-ET 3} & $\mathrm{c} 2$ & 8.309 & \\
\hline & c3 & & -1.208 \\
\hline & c5 & & -39.000 \\
\hline & c9 & -84.440 & \\
\hline
\end{tabular}




\begin{tabular}{llcc}
\hline & c0 & & 8.276 \\
Sub-ET 4 & c3 & & -5.480 \\
& c4 & 24.575 & \\
& c8 & 5.304 & 4.990 \\
\hline \multirow{3}{*}{ Sub-ET 5 } & c0 & & -8.681 \\
& c2 & & 4.979 \\
& c8 & & -3.628 \\
& c9 & & -0.260 \\
\hline
\end{tabular}

Performances of GEP models

In this modelling study, some statistical parameters were employed in the evaluation of performance of the formulas derived from the models in the GEP for estimating the $f_{c}$ of SCC produced with FA. These statistical parameters were the mean absolute percentage error (MAPE), root mean square error (RMSE) and R-square $\left(R^{2}\right)$. They were presented in Equations 7, 8 and 9, respectively. These equations were used to compare and evaluate the $f_{c \text {-exp. }}$ results of experimental works and the $f_{c \text {-pred. }}$. results of formulas attained from the models evolved in the GEP.

$$
\begin{aligned}
& M A P E=\frac{1}{n}\left[\sum_{i=1}^{n} \frac{\left|f_{(c-\text { exp. }) i}-f_{(c-\text { pred. }) i}\right|}{f_{(c-\text { exp }) i}} \times 100\right] \\
& R M S E=\sqrt{\frac{1}{n} \sum_{i=1}^{n}\left(f_{(c-\text { exp }) i}-f_{(c-\text { pred. }) i}\right)^{2}} \\
& R^{2}=\frac{\left(n \times \sum_{i=1}^{n}\left(f_{(c-\text { exp. }) i} \times f_{(c-\text { pred. }) i}\right)-\sum_{i=1}^{n}\left(f_{(c-\text { exp }) i} \times \sum_{i=1}^{n} f_{(c-\text { pred. }) i}\right)\right)^{2}}{\left(n \times \sum_{i=1}^{n}\left(f_{(c-\text { exp. }) i}\right)^{2}-\left(\sum_{i=1}^{n} f_{(c-\text { exp. }) i}\right)^{2}\right) \times\left(n \times \sum_{i=1}^{n}\left(f_{(c-\text { pred. }) i}\right)^{2}-\left(\sum_{i=1}^{n} f_{(c-\text { pred. }) i}\right)^{2}\right)}
\end{aligned}
$$

Where, $f_{c \text {-exp. is }}$ the target value attained from the experimental studies, $f_{c \text {-pred. }}$ is the output value obtained from the formulas and $n$ is the number of experimental data.

\section{Results and comparisons of GEP models}

The $f_{c \text {-pred. }}$ values attained from training and testing sets of both GEP models and the ANN (Golafshani \& Pazouki, 2018) models, and obtained from versus the $f_{c \text {-exp. }}$ values achieved from the experimental works of the SCC with FA are given in Figures 4 and 5 . In addition, the error values between the estimated results for both GEP models and the experimental work results are shown in Figures 6 and 7. The $f_{c \text {-pred. }}$ values handled from the training and testing sets in both GEP models are very close to the experimental work results as seen in Figures 4 and 5 . This closeness can be clearly seen by the $R^{2}$ values as given in Figures 4 and 5 . Moreover, as seen in Figures 6 and 7 , the error values between the estimated results for both GEP models and the experimental study results are very low. This situation shows the availability of formulas developed. Herein, when both GEP models are compared in terms of closeness to experimental results, the GEP-II model results are closer than that of GEP-I model ones. The number of genes (sub-ETs) used in the GEP-II model appears to be effective in this closeness. However, increasing the number of genes in the model causes the proposed formula more complex and diminish its usability. When the GEP models and the proposed ANN model are compared, it can be seen that the results of the ANN model are more appropriate to the experimental work results than that of the GEP models. On the other hand, in the proposed ANN model, there is no general formula that can be used by everyone like GEP models. Unused data in the training and testing sets of these models were used to measure the generalization capacity of the formulas obtained from the GEP models. This used data is also expressed as a validation set. The comparison of the results obtained from the validation set of the formulas obtained from both GEP models with the experimental study results is shown in Figure 8. Furthermore, the error values between the results obtained from the validation set of the formulas attained from the GEP models and the experimental results are given in Figure 9 . The 
validity and generalization capacity of the formulas given in Equations 4 and 6 attained from the GEP-I and the GEP-II models were verified by the validation set. This validation set underlines the main difference between GEP models and ANN ones.
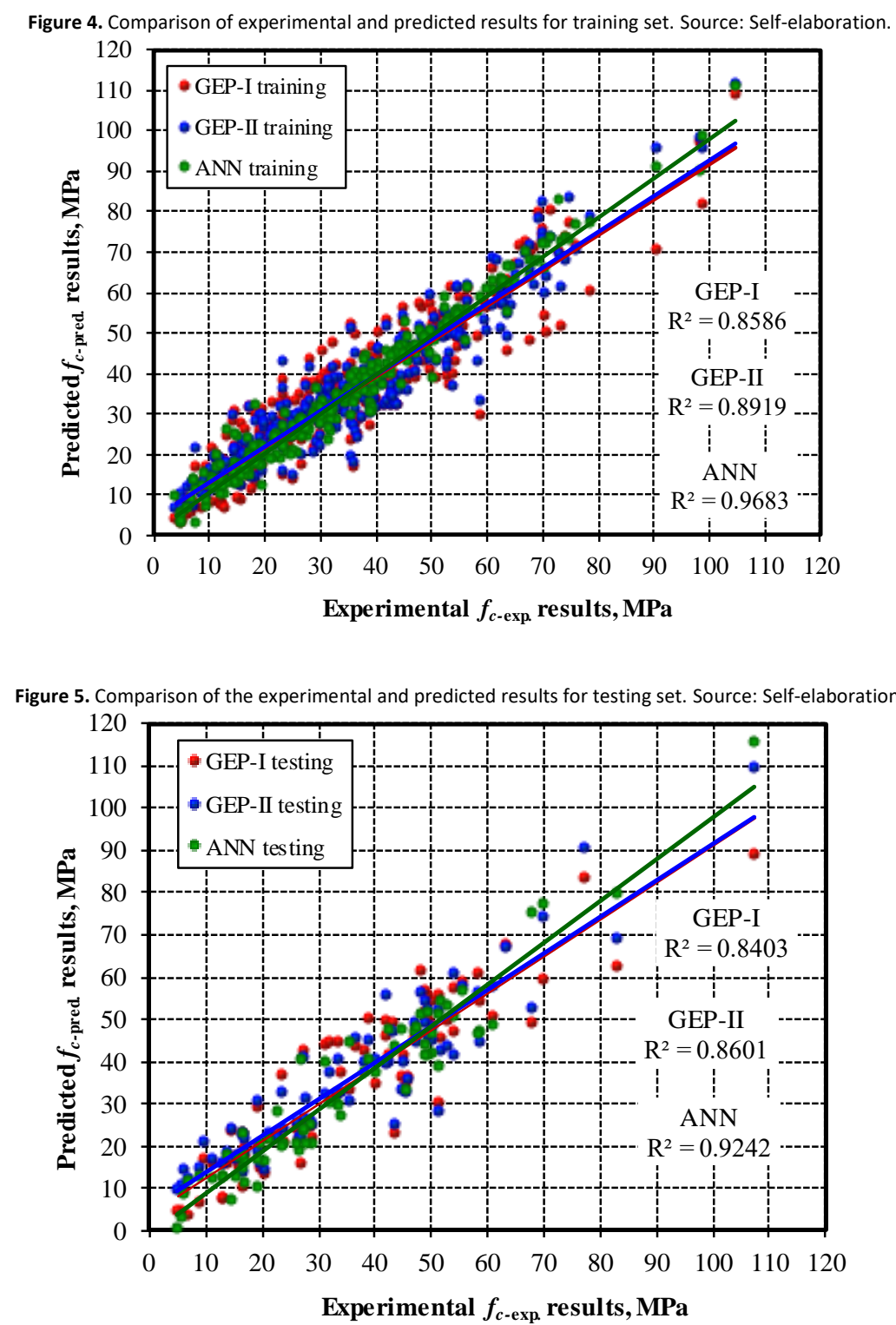

Figure 6. Error values between the experimental and predicted results for training set. Source: Self-elaboration.

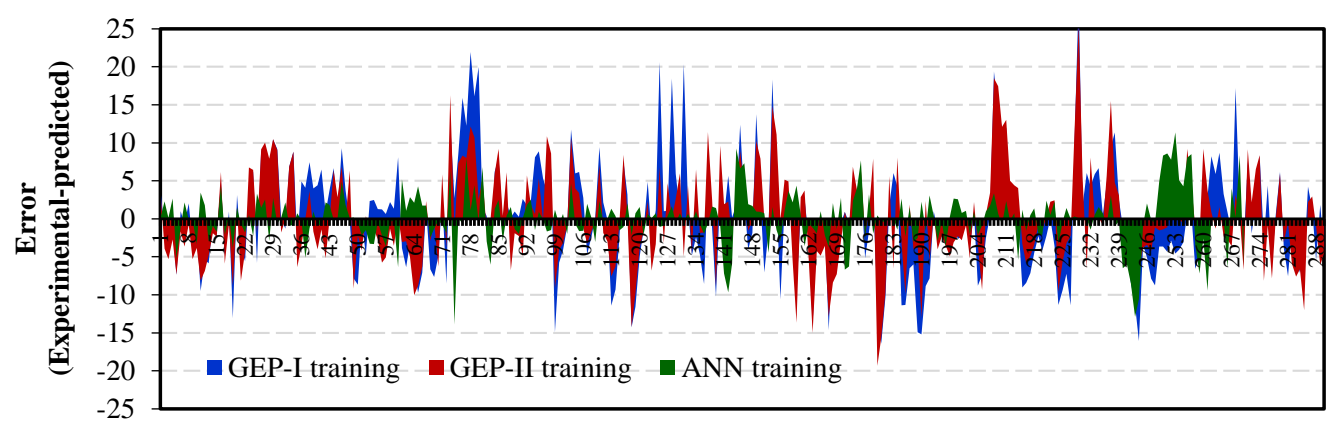

Training set samples 
Figure 7. Error values between the experimental and predicted results for testing set. Source: Self-elaboration.

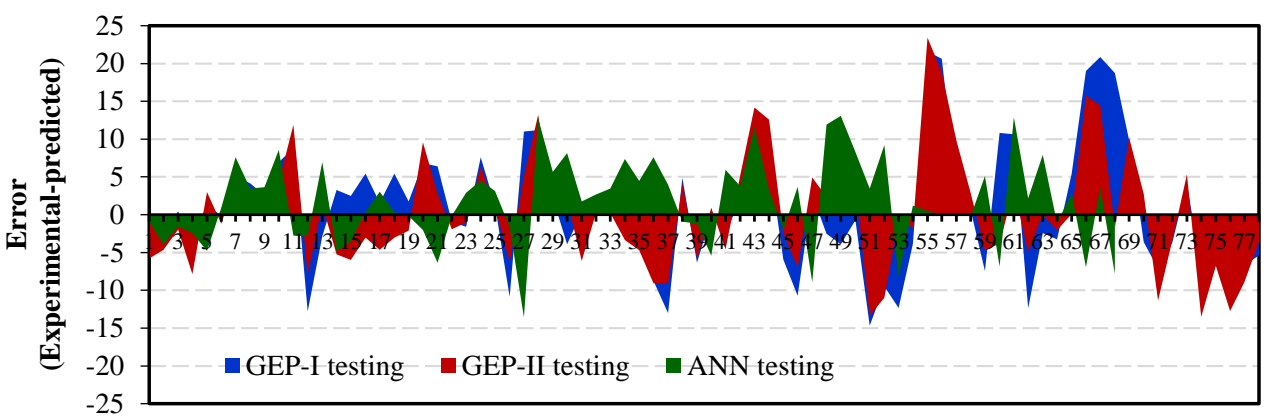

Testing set samples

Figure 8. Comparison of the experimental and predicted results for validation set. Source: Self-elaboration.

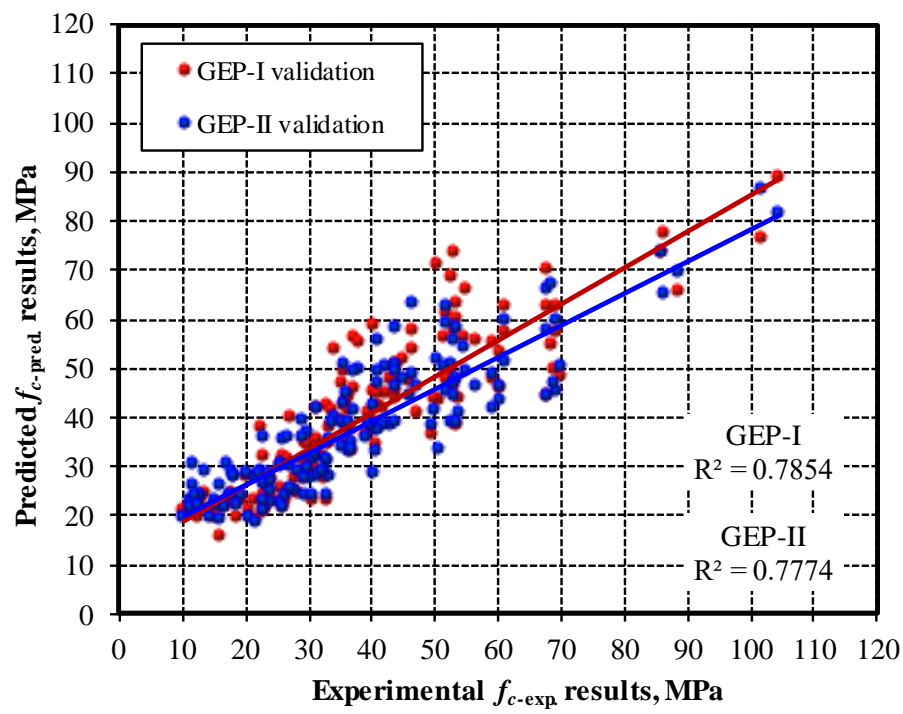

Figure 9. Error values between the experimental and predicted results for validation set. Source: Self-elaboration.

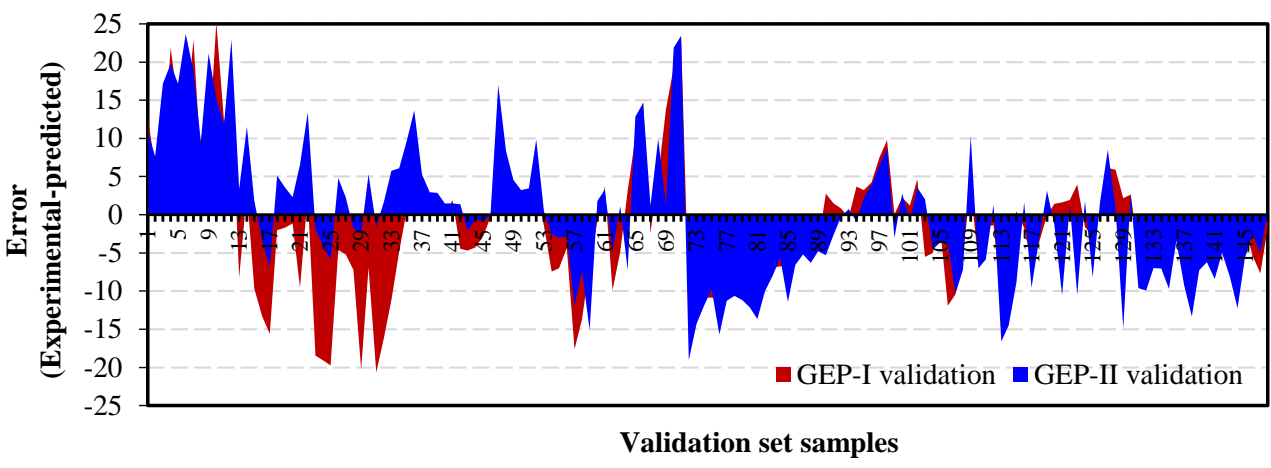

In this modelling study, the performances of both GEP models and the proposed ANN model (Golafshani \& Pazouki, 2018) were also evaluated by MAPE, RMSE and $R^{2}$ statistical parameter values. While the results of these statistical parameters for training, testing and validation sets used in both GEP models are given in Table 4, they could not be given for ANN model owing to have no validation set. According to the results of these statistical parameters, the developed GEP models can be employed to estimate the $f_{c}$ values of SCC produced with FA at various ages. When the GEP models were compared according to MAPE values, the highest MAPE value is 24.531 for the validation set of the model attained from the GEP-II, and the lowest MAPE valueis 18.658 for the training setofthe model attained from the GEP-II. Similarly, the highest RMSE value is 9.109 for the validation set of the model attained from the GEP-II, and the lowest RMSE value is 6.304 for the training set ofthe model attained from the GEP-II. $R^{2}$ of both GEP models for the sets are larger than 0.777, as given in Table 4. When the models attained from the GEP were compared in reference to $R^{2}$ values, the best $R^{2}$ value is 0.892 for the training set of the model attained from the GEP-II as the lowest $R^{2}$ value of is 0.777 for the validation set of the model attained from the GEP-II. The statistical parameter values show that $f_{c}$ values of SCC produced 
with FA can be estimated by these formulas and these formulas can be used by everyone. The $\mathrm{R}^{2}$ values of the ANN model developed by Golafshani and Pazouki (Golafshani \& Pazouki, 2018) are larger than that of the GEP models. However, in the previously proposed ANN model according to the formulas obtained from GEP models, there is no suggested an equation that everyone can use. In this respect, it is thought that GEP models may have more widespread effects than the previously proposed ANN model. The results of validation set show that the formulas obtained by using GEP models are able to be generalized among the output and inputs. Moreover, the $f_{c}$ values of the SCC with FA can be closely predicted to the experimental results in a short time by using the formulas obtained from these models.

\begin{tabular}{|c|c|c|c|c|c|c|c|c|c|}
\hline & \multicolumn{3}{|c|}{ MAPE } & \multicolumn{3}{|c|}{ RMSE } & \multicolumn{3}{|c|}{$R^{2}$} \\
\hline & Training & Testing & Validation & Training & Testing & Validation & Training & Testing & Validation \\
\hline GEP-I & 19.826 & 20.157 & 21.792 & 7.211 & 7.983 & 8.760 & 0.859 & 0.840 & 0.785 \\
\hline GEP-II & 18.658 & 22.561 & 24.531 & 6.304 & 7.411 & 9.109 & 0.892 & 0.860 & 0.777 \\
\hline ANN & 10.592 & 17.834 & - & 3.405 & 5.849 & - & 0.968 & 0.924 & - \\
\hline
\end{tabular}

In this modelling study, the formulas attained from the GEP-I and GEP-II models developed by utilizing GEP technique were employed to estimate $f_{c}$ values of SCC produced with FA at various ages. The input and output variables attained from experimental studies were employed in the training and testing sets of the models developed in GEP technique. Then, the formulas obtained from these models validated by using the input variables obtained from experimental studies, which are not used in the training and testing sets of the models. The results of sets of the models showed that the $f_{c \text {-exp. }}$ results of the SCC produced with FA at different ages could be closely predicted with proposed formulas. The

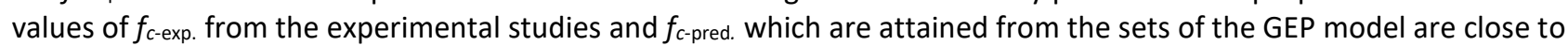
each other. This closeness can be explainedin terms of MAPE, RMSE and $R^{2}$ statistical parameter values for two novel mathematical formulas based on the models attained from the GEP-I and GEP-II. Thus, the $f_{c}$ values of SCC produced with FA at different ages can be estimated in a short period with very small error rates by utilizing the equations obtained from GEP models.

References

Abdalhmid, J. M., Ashour, A. F., \& Sheehan, T. (2019). Long-term drying shrinkage of self-compacting concrete: Experimental and analytical investigations. Construction and Building Materials, 202, 825-837. https://doi.org/10.1016/j.conbuildmat.2018.12.152

Acar Yildirim, H., \& Akcay, C. (2019). Time-cost optimization model proposal for construction projects with genetic algorithm and fuzzy logic approach. Revista de la Construcción, 18(3), 554-567. https://doi.org/10.7764/rdlc.18.3.554

Ashtiani, M. S., Scott, A. N., \& Dhakal, R. P. (2013). Mechanical and fresh properties of high-strength self-compacting concrete containing class C fly ash. Construction and Building Materials, 47, 1217-1224. https://doi.org/10.1016/j.conbuildmat.2013.06.015

Baykasoğlu, A., Dereli, T., \& Taniş, S. (2004). Prediction of cement strength using soft computing techniques. Cement and Concrete Research, 34(11), 2083-2090. https://doi.org/10.1016/j.cemconres.2004.03.028

Bingöl, A. F., \& Tohumcu, I. (2013). Effects of different curing regimes on the compressive strength properties of self compacting concrete incorporating fly ash and silica fume. Materials and Design, 51, 12-18. https://doi.org/10.1016/j.matdes.2013.03.106

Bouzoubaâ, N., \& Lachemi, M. (2001). Self-compacting concrete incorporating high volumes of class F fly ash: Preliminary results. Cement and Concrete Research, 31(3), 413-420. https://doi.org/10.1016/50008-8846(00)00504-4

Bui, V. K., Akkaya, Y., \& Shah, S. P. (2002). Rheological model for self-consolidating concrete. ACl Materials Journal, 99(6), 549-559.

Da Silva, P. R., \& De Brito, J. (2015). Experimental study of the porosity and microstructure of self-compacting concrete (SCC) with binary and ternary mixes of fly ash and limestone filler. Construction and Building Materials, 86, 101-112. https://doi.org/10.1016/j.conbuildmat.2015.03.110

El-Chabib, H., \& Syed, A. (2013). Properties of self-consolidating concrete made with high volumes of supplementary cementitious materials. Journal of Materials in Civil Engineering, 25(11), 1579-1586. https://doi.org/10.1061/(asce)mt.1943-5533.0000733

Eskandari-Naddaf, H., \& Kazemi, R. (2017). ANN prediction of cement mortar compressive strength, influence of cement strength class. Construction and Building Materials, 138, 1-11. https://doi.org/10.1016/j.conbuildmat.2017.01.132

Ferreira, C. (2001a). Gene expression programming: a new adaptive algorithm for solving problems. Complex Systems, 13(2), 1-20.

Ferreira, C. (2001b). Gene expression programming in problem solving. WSC6 Tutorial, (1992), 1-22. https://doi.org/10.1007/978-1-4471-0123-9_54

Gandomi, A. H., Alavi, A. H., Ting, T. O., \& Yang, X. S. (2013). Intelligent modeling and prediction of elastic modulus of concrete strength via gene expression programming. In Advances in Swarm Intelligence. ICSI 2013 Lecture Notes in Computer Science (pp. 564-571). Harbin: Springer Berlin Heidelberg. https://doi.org/10.1007/978-3-642-38703-6_66 
Gesoğlu, M., \& Özbay, E. (2007). Effects of mineral admixtures on fresh and hardened properties of self-compacting concretes: Binary, ternary and quaternary systems. Materials and Structures/Materiaux et Constructions, 40(9), 923-937. https://doi.org/10.1617/s11527-007-9242-0

Gholampour, A., Gandomi, A. H., \& Ozbakkaloglu, T. (2017). New formulations for mechanical properties of recycled aggregate concrete using gene expression programming. Construction and Building Materials, 130, 122-145. https://doi.org/10.1016/j.conbuildmat.2016.10.114

Golafshani, E. M., \& Pazouki, G. (2018). Predicting the compressive strength of self-compacting concrete containing fly ash using a hybrid artificial intelligence method. Computers and Concrete, 22(4), 419-437. https://doi.org/10.12989/cac.2018.22.4.419

Golafshani, E. M., Rahai, A., \& Sebt, M. H. (2014). Bond behavior of steel and GFRP bars in self-compacting concrete. Construction and Building Materials, 61, 230-240. https://doi.org/10.1016/j.conbuildmat.2014.02.021

Güneyisi, E., Gesoglu, M., Al-Goody, A., \& Ipek, S. (2015). Fresh and rheological behavior of nano-silica and fly ash blended self-compacting concrete. Construction and Building Materials, 95, 29-44. https://doi.org/10.1016/j.conbuildmat.2015.07.142

Güneyisi, E., Gesoglu, M., \& Özbay, E. (2010). Strength and drying shrinkage properties of self-compacting concretes incorporating multi-system blended mineral admixtures. Construction and Building Materials, 24(10), 1878-1887. https://doi.org/10.1016/j.conbuildmat.2010.04.015

Jafari, S., \& Mahini, S. S. (2017). Lightweight concrete design using gene expression programing. Construction and Building Materials, 139, 93-100. https://doi.org/10.1016/j.conbuildmat.2017.01.120

Jalal, M., Fathi, M., \& Farzad, M. (2013). Effects of fly ash and TiO2 nanoparticles on rheological, mechanical, microstructural and thermal properties of high strength self compacting concrete. Mechanics of Materials, 61, 11-27. https://doi.org/10.1016/j.mechmat.2013.01.010

Kara, I. F. (2011). Prediction of shear strength of FRP-reinforced concrete beams without stirrups based on genetic programming. Advances in Engineering Software, 42(6), 295-304. https://doi.org/10.1016/j.advengsoft.2011.02.002

Khan, R. A., \& Sharma, A. (2015). Durability properties of self compacting concrete containing fly ash, lime powder and metakaolin. Journal of Materials and Engineering Structures, 2(4), 206-212.

Khatib, J. M. (2008). Performance of self-compacting concrete containing fly ash. Construction and Building Materials, $22(9)$, $1963-1971$. https://doi.org/10.1016/j.conbuildmat.2007.07.011

Krishnapal, P., Rajeev, C., \& Kumar, D. S. (2012). Development and properties of self compacting concrete mixed with fly ash. Research Journal of Engineering Sciences, 1(3), 11-14.

Le, H. T., \& Ludwig, H. M. (2016). Effect of rice husk ash and other mineral admixtures on properties of self-compacting high performance concrete. Materials and Design, 89, 156-166. https://doi.org/10.1016/j.matdes.2015.09.120

Leung, H. Y., Kim, J., Nadeem, A., Jaganathan, J., \& Anwar, M. P. (2016). Sorptivity of self-compacting concrete containing fly ash and silica fume. Construction and Building Materials, 113, 369-375. https://doi.org/10.1016/j.conbuildmat.2016.03.071

Lim, C. H., Yoon, Y. S., \& Kim, J. H. (2004). Genetic algorithm in mix proportioning of high-performance concrete. Cement and Concrete Research, 34(3), 409-420. https://doi.org/10.1016/j.cemconres.2003.08.018

Liu, M. (2010). Self-compacting concrete with different levels of pulverized fuel ash. Construction and Building Materials, $24(7), 1245-1252$. https://doi.org/10.1016/j.conbuildmat.2009.12.012

Madihalli, R., Saunshi, B., \& Thakai, R. J. (2016). Experimental study on fresh \& hardened properties of self compacting concrete containing manufactured sand \&fly ash. International Journal of Informative \& Futuristic Research, 3(6), 1959-1971.

Mahdinia, S., Eskandari-Naddaf, H., \& Shadnia, R. (2019). Effect of cement strength class on the prediction of compressive strength of cement mortar using GEP method. Construction and Building Materials, 198, 27-41. https://doi.org/10.1016/j.conbuildmat.2018.11.265

Melo, K. A., \& Carneiro, A. M. P. (2010). Effect of metakaolin's finesses and content in self-consolidating concrete. Construction and Building Materials, 24(8), 1529-1535. https://doi.org/10.1016/j.conbuildmat.2010.02.002

Mohamed, H. A. (2011). Effect of fly ash and silica fume on compressive strength of self-compacting concrete under different curing conditions. Ain Shams Engineering Journal, 2(2), 79-86. https://doi.org/10.1016/j.asej.2011.06.001

Mousavi, S. M., Aminian, P., Gandomi, A. H., Alavi, A. H., \& Bolandi, H. (2012). A new predictive model for compressive strength of HPC using gene expression programming. Advances in Engineering Software, 45(1), 105-114. https://doi.org/10.1016/j.advengsoft.2011.09.014

Nagarajan, D., Rajagopal, T., \& Meyappan, N. (2020). A comparative study on prediction models for strength properties of LWA concrete using artificial neural network. Revista de La Construcción, 103-111. https://doi.org/10.7764/rdlc.19.1.103-111

Nakata, I. M., Fernández, F. G., Carrillo, A. T., Haro, P. E., \& Pinaud, L. A. (2018). Application of the Monte Carlo method to estimate the uncertainty in the compressive strength test of high-strength concrete modelled with a multilayer perceptron. Revista de La Construccion, 17(2), 319-329. https://doi.org/10.7764/RDLC.17.2.319

Nazari, A. (2019a). Application of gene expression programming to predict the compressive damage of lightweight aluminosilicate geopolymer. Neural Computing and Applications, 31(S2), 767-776. https://doi.org/10.1007/s00521-012-1137-5

Nazari, A. (2019b). Predicting the total specific pore volume of geopolymers produced from waste ashes by gene expression programming. Neural Computing and Applications, 31(S2), 751-757. https://doi.org/10.1007/s00521-012-1135-7

Nazari, A., \& Riahi, S. (2011). Computer-aided design of the effects of Cr2O3 nanoparticles on split tensile strength and water permeability of high strength concrete. Science China Technological Sciences, 54(3), 663-675. https://doi.org/10.1007/s11431-010-4266-z 
Nazari, A., \& Riahi, S. (2013). Predicting the effects of nanoparticles on compressive strength of ash-based geopolymers by gene expression programming. Neural Computing and Applications, 23(6), 1677-1685. https://doi.org/10.1007/s00521-012-1127-7

Ozawa, K., Maekawa, K., \& Okamura, H. (1990). High performance concrete with high filling ability. In Rilem International Symposium On Admixtures For Concrete: Improvement Of Properties (pp. 51-62). London: Chapman and Hall Limited. Retrieved from http://worldcat.org/isbn/0412374102

Patel, R., Hossain, K. M. A., Shehata, M., Bouzoubaâ, N., \& Lachemi, M. (2004). Development of statistical models for mixture design of high-volume fly ash self-consolidating concrete. ACl Materials Journal, 101(4), 294-302.

Pathak, N., \& Siddique, R. (2012). Properties of self-compacting-concrete containing fly ash subjected to elevated temperatures. Construction and Building Materials, 30, 274-280. https://doi.org/10.1016/j.conbuildmat.2011.11.010

Pofale, A. D., \& Deo, S. V. (2010). Comparative long term study of concrete mix design procedure for fine aggregate replacement with fly ash by minimum voids method and maximum density method. KSCE Journal of Civil Engineering, 14(5), 759-764. https://doi.org/10.1007/s12205-0100911-0

Prendes-Gero, M. B., Bello-García, A., Coz-Díaz, J. J. del, Suárez-Domínguez, F. J., \& Nieto, P. J. G. (2018). Optimization of steel structures with one genetic algorithm according to three international building codes. Revista de La Construccion, $17(1)$, 47-59. https://doi.org/10.7764/RDLC.17.1.47

Şahmaran, M., Lachemi, M., Erdem, T. K., \& Yücel, H. E. (2011). Use of spent foundry sand and fly ash for the development of green self-consolidating concrete. Materials and Structures/Materiaux et Constructions, 44(7), 1193-1204. https://doi.org/10.1617/s11527-010-9692-7

Sarıdemir, M. (2010). Genetic programming approach for prediction of compressive strength of concretes containing rice husk ash. Construction and Building Materials, 24, 1911-1919. https://doi.org/10.1016/j.conbuildmat.2010.04.011

Sarıdemir, M. (2014). Effect of specimen size and shape on compressive strength of concrete containing fly ash: Application of genetic programming for design. Materials and Design, 56, 297-304. https://doi.org/10.1016/j.matdes.2013.10.073

Sarıdemir, M., \& Severcan, M. H. (2016). The use of genetic programming and regression analysis for modeling the modulus of elasticity of NSC and HSC. Arabian Journal for Science and Engineering, 41(10), 3959-3967. https://doi.org/10.1007/s13369-016-2043-4

Satish, K., Kumar, S., \& Rai, B. (2017). Self compacting concrete using fly ash and silica fumes as pozzolanic material. Journal of Engineering Technology (ISSN: 0747-9964), 6(2), 394-407.

Severcan, M. H. (2012). Prediction of splitting tensile strength from the compressive strength of concrete using GEP. Neural Computing and Applications, 21(8), 1937-1945. https://doi.org/10.1007/s00521-011-0597-3

Siad, H., Mesbah, H. A., Mouli, M., Escadeillas, G., \& Khelafi, H. (2014). Influence of mineral admixtures on the permeation properties of selfcompacting concrete at different ages. Arabian Journal for Science and Engineering, 39(5), 3641-3649. https://doi.org/10.1007/s13369-014$1055-1$

Siddique, R. (2011). Properties of self-compacting concrete containing class F fly ash. Materials and Design, $32(3)$, $1501-1507$. https://doi.org/10.1016/j.matdes.2010.08.043

Siddique, R., Aggarwal, P., \& Aggarwal, Y. (2012a). Influence of water/powder ratio on strength properties of self-compacting concrete containing coal fly ash and bottom ash. Construction and Building Materials, 29, 73-81. https://doi.org/10.1016/j.conbuildmat.2011.10.035

Siddique, R., Aggarwal, P., \& Aggarwal, Y. (2012b). Mechanical and durability properties of self-compacting concrete containing fly ash and bottom ash. Journal of Sustainable Cement-Based Materials, 1(3), 67-82. https://doi.org/10.1080/21650373.2012.726820

Sonebi, M. (2004). Medium strength self-compacting concrete containing fly ash: Modelling using factorial experimental plans. Cement and Concrete Research, 34(7), 1199-1208. https://doi.org/10.1016/j.cemconres.2003.12.022

Sonebi, M., \& Cevik, A. (2009). Prediction of fresh and hardened properties of self-consolidating concrete using neurofuzzy approach. Journal of Materials in Civil Engineering, 21(11), 672-679. https://doi.org/10.1061/(asce)0899-1561(2009)21:11(672)

Sukumar, B., Nagamani, K., \& Srinivasa Raghavan, R. (2008). Evaluation of strength at early ages of self-compacting concrete with high volume fly ash. Construction and Building Materials, 22(7), 1394-1401. https://doi.org/10.1016/j.conbuildmat.2007.04.005

Topçu, I. B., \& Sarıdemir, M. (2008). Prediction of rubberized concrete properties using artificial neural network and fuzzy logic. Construction and Building Materials, 22(4), 532-540. https://doi.org/10.1016/j.conbuildmat.2006.11.007

Ulucan, Z. Ç., Türk, K., \& Karataş, M. (2008). Effect of mineral admixtures on the correlation between ultrasonic velocity and compressive strength for self-compacting concrete. Russian Journal of Nondestructive Testing, 44(5), 367-374. https://doi.org/10.1134/s1061830908050100

Wang, L., Zhang, G., Wang, P., \& Yu, S. (2018). Effects of fly ash and crystalline additive on mechanical properties of two-graded roller compacted concrete in a high RCC arch dam. Construction and Building Materials, 182, 682-690. https://doi.org/10.1016/j.conbuildmat.2018.06.101

Yahia, A., Tanimura, M., Shimabukuro, A., \& Shimoyama, Y. (1999). Effect of rheological parameters on self-compactibility of concrete containing various mineral admixtures. In International symposium; 1st, Self-compacting concrete (pp. 523-536). Stockholm: RILEM.

Zhao, H., Sun, W., Wu, X., \& Gao, B. (2015). The properties of the self-compacting concrete with fly ash and ground granulated blast furnace slag mineral admixtures. Journal of Cleaner Production, 95, 66-74. https://doi.org/10.1016/j.jclepro.2015.02.050

Zhu, W., Gibbs, J. C., \& Bartos, P. J. M. (2001). Uniformity of in situ properties of self-compacting concrete in full-scale structural elements. Cement and Concrete Composites, 23(1), 57-64. https://doi.org/10.1016/S0958-9465(00)00053-6 